\title{
市販注射剤の物理的性状と溶血性との関係および 溶血性の減弱化について*1
}

\author{
田中尚純，岩松ちづ子，鄭 富三，堀内信子*2 \\ 甲府共立病院薬哓部*2
}

\section{Hemolytic Property of Injections of Different pH Values and Osmotic Pressures*1}

\author{
Hisayoshi TANAKa, Chizuko IWAmatsu, Tomizo TEI \\ and NOBUKO HORIUCHI*2 \\ Pharmacy, Kofu Kyoritsu Hospital*2
}

\begin{abstract}
Hemolytic property of the solutions of various $\mathrm{pH}$ values and osmotic pressures were studied. Of these solutions and 280 commercial injections studied, those of $\mathrm{pH}$ under or above the range of 4.5-11.0 or the osmotic pressures under or above $0.5-5.0$ generally showed hemolytic property. Hemolytic action of most of the commercial injections having low osmotic pressures was reduced or disappeared, when sodium chloride was added to the injections to prepare isotonic solutions. The same phenomenon was generally observed when the injections having the hemolytic effect were mixed with $0.5-3.0 \mathrm{ml}$ of isotonic sodium chloride solution or with other injections. From these results, manufacture of safe commercial injections by the adjustment of osmotic pressure or the modification of dosage strength was required. Further, data for safe administration of intramuscular injections were obtained.
\end{abstract}

\section{は じめに}

前報1)において，著者らは市販注射剂の $\mathrm{pH}$ 値，浸透圧 比および溶血性の程度と添付文書記載の適用部位（以下 適用部位と省略）との関係並びに数社で製造している同 一主成分含有の注射剤間における性状の差を比較検討し た. 今回, 引続き, 市販注射剂 96 種の性状を試験し, また，製剤上あるいは筋肉内適用上の溶血性の低減化を 目的として, $\mathrm{pH}$ 值および浸透圧比と溶血性との関係並 びに混注による溶血性の変化を検討した。

\section{実 験 の 部}

\section{1. 試料}

1）市販注射剂：今回新たに試料に用いた容量 $20 \mathrm{ml}$ 以下の市販注射剤 96 種は表 1 に示した。

2）各 $\mathrm{pH}$ 值溶液：血液と等張とされている Michael$\mathrm{is}^{2)}$ のバルビタールナトリウムー酢酸ナトリウムー塩酸緩 衝液に準じて $\mathrm{pH} 7.77$ 以下の溶液を，また， $0.1 \mathrm{~N}$ 塩酸 の代わりに $0.1 \mathrm{~N}$ 水酸化ナトリウムを用いて, $\mathrm{pH} 9.39$

*1 本報を注射剤の物理化学的性状の検討 (第 2 報) と する。

*2 甲府市宝 1 丁目 9-1；9-1，Takara 1-chome， Kofu-shi, Yamanashi, 400 Japan

\section{以上の溶液を調製した.}

3）各浸透圧比溶液：生理食塩液に対する浸透圧比 0.1 10をもつ各種濃度の塩化ナトリウム溶液を調製し た。

2. pH 值測定, 浸透圧比測定および溶血性試験

前報と同様に行った.

\section{結果および考察}

\section{1. pH 值および浸透圧比と溶血性との関係}

\section{a） $\mathbf{p H}$ 值と溶血性との関係}

各 $\mathrm{pH}$ 僆溶液について溶血性の程度を試験し, その結 果を表 2 に示した. pH 4.55〜10.91の範囲内では溶血性 が認められなかったが，それ以外では $\mathrm{pH}$ 值が極端になる につれて，強い溶血性がみられた。この結果から，注射 剤の溶血性にはその $\mathrm{pH}$ 值も影響することが確認され，一 般的に溶血性のない注射剤として望ましい範囲は, $\mathrm{pH}$ 4.5〜11.0 の間が適当と考えられる.

\section{b）浸透圧比と溶血性との関係}

各浸透圧比溶液について溶血性を試験し，その結果を 表 3 に示した. 浸透圧比 $0.6 \sim 4.1$ の範囲内では溶血性 が認められず，同様の検討による赤石ら ${ }^{3)}$ の報告と異な った結果が得られた。また，浸透圧比 0.5 および 5.3 で 
表 1 . 市販注射剤の $\mathrm{pH}$ 佰，浸透圧比および溶血性

\begin{tabular}{|c|c|c|c|c|c|c|c|c|c|c|}
\hline \multirow{2}{*}{ 薬効分類名 } & \multirow{2}{*}{ 注 射 郕 名 } & \multirow{2}{*}{ 規 格 } & \multirow{2}{*}{ 製造番号 } & \multirow{2}{*}{ pH值 } & \multirow{2}{*}{$\begin{array}{l}\text { 浸透 } \\
\text { 圧比 }\end{array}$} & \multirow{2}{*}{$\begin{array}{l}\text { 溶血 } \\
\text { 性 } \\
\end{array}$} & \multicolumn{3}{|c|}{ 適用部位 } & \multirow{2}{*}{ 備 考 } \\
\hline & & & & & & & 皮下 & 筋 & 静 & \\
\hline \multirow[t]{5}{*}{ 解 熱鎮 痛郕 } & イルガピリン & $3 m \ell$ & 6490 & 9.8 & 4.2 & 曲 & & O & & \\
\hline & サリミッド & $10 m \ell$ & YOW061 & 6.7 & 1.6 & - & & & 0 & \\
\hline & カシワドール & $20 m \ell$ & 663 & 5.6 & 1.1 & - & & & D) & \\
\hline & サンピリン 2 号 & $1 \mathrm{ml}$ & B23VD & 7.1 & 11.3 & 冊 & $O$ & O & 0 & \\
\hline & セダポリシン & $10 \mathrm{~m} \ell$ & GK09A2 & 5.6 & 3.3 & H & & & $\bigcirc$ & \\
\hline 賞せ い剤 & アンコーマ & $20 \% \quad 20 \mathrm{ml}$ & $\mathrm{MXC} 041$ & 7.2 & 8.2 & - & & & 0 & \\
\hline 鎮 量 剂 & トラベルミン & $1 \mathrm{m \ell}$ & D09BH & 6.4 & 1.1 & Ht & $O$ & O & & \\
\hline \multirow[t]{6}{*}{ 精神神経用剂 } & ウインタミン & $0.5 \% 5 \mathrm{~m} \ell$ & E210U & 5.5 & 1.0 & Ht & & O & $\bigcirc$ & \\
\hline & ウインタミン & $2.5 \% 2 \mathrm{~m} \ell$ & & 5.8 & 1.0 & H & & $\bigcirc$ & 0 & \\
\hline & ピーゼットシー & $0.2 \% 1 \mathrm{ml}$ & YT1003 & 5.4 & 0.9 & H & & O & 0 & \\
\hline & ノバミン & $0.5 \%{ }^{\circ} 1 \mathrm{~m} \ell$ & & 5.9 & 1.3 & $H$ & & 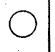 & & \\
\hline & セルシン & $10 \mathrm{mg}$ & OWI064 & 6.6 & 10.9 & H & & $\bigcirc$ & 0 & $\therefore$ \\
\hline & アタラックスーP & $5 \% \quad 1 \mathrm{m \ell}$ & $406-271145 \mathrm{R}$ & 4.8 & 1.2 & HI & & 0 & $\bigcirc$ & \\
\hline 自律神経用剂 & イミダリン & $2 \% \quad 1 m \ell$ & DDD1 & 6.4 & 0.6 & \# & $O$ & & & \\
\hline 鎮 痓 剂 & レジタン & $1 \% \quad 1 \mathrm{~m} \ell$ & 013UCZ & 4.9 & 0.9 & + & 0 & $\bigcirc$ & $\bigcirc$ & \\
\hline \multirow[t]{4}{*}{ 抗ヒスタミン剤 } & マレイン酸クロルフェニラシン & $0.5 \% 1 \mathrm{~m} \ell$ & & 4.9 & 1.2 & H & ) & 0 & $\bigcirc$ & 北陸 \\
\hline & クロールトリメトン & $1 \% \quad 1 m \ell$ & $\mathrm{B} 210 \mathrm{Z}$ & 5.0 & 0.1 & \# & $D$ & $\bigcirc$ & $\bigcirc$ & \\
\hline & ピレチア & $0.5 \% 2 \mathrm{ml}$ & & 5.8 & 0.2 & H & 0 & 0 & & \\
\hline & ピレチア & $2.5 \% 1 \mathrm{~m} t$ & & 6.0 & 0.3 & 冊 & 0 & O & & \\
\hline \multirow[t]{3}{*}{ 剌 激 䝤 法 剂 } & シオゾール & $10 \mathrm{mg} \quad 1 \mathrm{~m} \ell$ & $\mathrm{Z} 210 \mathrm{Z}$ & 6.8 & 1.0 & - & & $O$ & & ' \\
\hline & シオゾール & $25 m g \quad 1 m \ell$ & $\mathrm{Z} 410 \mathrm{R}$ & 6.6 & 1.2 & - & & 0 & & \\
\hline & シオゾール & $50 \mathrm{mg} \quad 1 \mathrm{~m} \ell$ & $\mathrm{B} 610 \mathrm{Z}$ & 6.4 & 1.4 & - & & $\bigcirc$ & & \\
\hline \multirow[t]{2}{*}{ 強 心 剂 } & インテンザイン & $20 m g$ & OR1037 & 6.6 & 1.1 & + & & & $\bigcirc$ & \\
\hline & 強カルヂノン & $1 \mathrm{ml}$ & & 5.3 & 1.0 & H & 0 & 0 & & \\
\hline 利尿剂 & アポプレクタール & $5 m \ell$ & $\mathrm{K} 5 \mathrm{C} 2210$ & 5.4 & 2.4 & H & & & D & \\
\hline \multirow[t]{2}{*}{ 血管収緶剂 } & ネオシネジン 1 号 & $0.1 \% 1 \mathrm{ml}$ & NC527K & 2.8 & 1.0 & - & 0 & 0 & & \\
\hline & ネオシネジン 2 号 & $0.5 \% 1 \mathrm{ml}$ & NJ322W & 3.0 & 1.0 & - & $O$ & $\bigcirc$ & & \\
\hline \multirow[t]{4}{*}{ その他の循環器官用凨 } & プロセリール & $250 \mathrm{mg}$ & $113 \mathrm{~K}$ & 3.8 & 0.5 & HW & & $\bigcirc$ & & \multirow{4}{*}{$\begin{array}{l}250 \mathrm{mg} / 10 \mathrm{ml} \\
\text { 注射用蒸留水 } \\
\text { 田辺 }\end{array}$} \\
\hline & ニコリン & $12.5 \% 2 \mathrm{~m} \ell$ & S005 & 7.2 & 1.8 & - & & $\bigcirc$ & $\bigcirc$ & \\
\hline & バスクラート & $5 \% \quad 1 \mathrm{ml}$ & & 2.8 & 0.9 & + & . & $\bigcirc$ & & \\
\hline & ユークリダン & $50 m g$ & & 3.8 & 1.5 & - & & $O$ & & \\
\hline 呼吸促進剂 & ロルファン & $0.1 \% \quad 1 \mathrm{~m} \ell$ & 0006 & 3.6 & 1.0 & + & $\bigcirc$ & 0 & $\bigcirc$ & \\
\hline \multirow[t]{2}{*}{ 鎮 咳袪痰剂 } & イノリン & $0.1 \mathrm{mg}$ & KG15036G & 5.0 & 1.0 & - & 0 & $\bigcirc$ & 0 & \\
\hline & アセトセダンー0 & $0.5 \mathrm{~m} \ell$ & N009 S & 2.9 & 0.6 & H & $\bigcirc$ & & & \\
\hline \multirow[t]{3}{*}{ 消化器官用薬 } & キャベジンU & $500 \mathrm{mg}$ & & 4.7 & 2.6 & - & & & 0 & \\
\hline & ザウエルプラセンタ & $2.2 m \ell$ & OD240 & 5.9 & 2.3 & \# & & $\bigcirc$ & & \\
\hline & スルフィニン & $5 \mathrm{mg}$ & & -4.4 & -1.6 & H & 0 & & $\bigcirc$ & \\
\hline
\end{tabular}




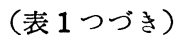

\begin{tabular}{|c|c|c|c|c|c|c|c|c|c|c|}
\hline \multirow{2}{*}{ 薬効分類名 } & \multirow{2}{*}{ 注 射 剂 名 } & \multirow{2}{*}{ 規 格 } & \multirow{2}{*}{ 製造番号 } & \multirow{2}{*}{$\mathrm{pH}$ 值 } & \multirow{2}{*}{$\begin{array}{l}\text { 漫透 } \\
\text { 圧比 }\end{array}$} & \multirow{2}{*}{ 溶血 } & \multicolumn{3}{|c|}{ 適用部位 } & \multirow{2}{*}{ 備 考 } \\
\hline & & & & & & & 皮下 & 筋 & 静 & \\
\hline \multirow[t]{3}{*}{ 消化器官用薬 } & リポトリン静脈用 & $10 \% \quad 5 \mathrm{~m} \ell$ & D09HJ & 8.4 & 4.8 & - & & & $\bigcirc$ & \\
\hline & エンテリン & $0.5 \% 2 \mathrm{ml}$ & APQ815-2 & 6.4 & 1.1 & - & 0 & & 0 & \\
\hline & インタセリン & $2 m \ell$ & 073 & 7.0 & 1.1 & - & 0 & $\bigcirc$ & & \\
\hline \multirow[t]{6}{*}{ 脳下垂体ホルモン剤 } & ネオプロセリン & 3,000 単位 & & 4.7 & 1.7 & - & & $\bigcirc$ & & \\
\hline & コートロシン & $0.25 \mathrm{mg}$ & $1142 \mathrm{TGX}$ & 6.5 & 1.1 & - & & $\bigcirc$ & $\bigcirc$ & \\
\hline & コートロシンZ Z & $1 \mathrm{mg}$ & $1215 \mathrm{TAZ}$ & 8.5 & 1.2 & + & & $\bigcirc$ & & \\
\hline & アトニンー0 & 5 単位. & G3 & 2.7 & 0.1 & H & 0 & 0 & & \\
\hline & アトニン & 5 単位 & FCIE3 & 3.4 & 0.2 & 冊 & & 0 & & \\
\hline & HCGモチダ & 5,000 単位 & S60309D042N6 & 5.4 & 1.0 & - & & 0 & & \\
\hline 甲状腺ホルモン剂 & メルカゾール & $10 \mathrm{mg}$ & $212 \mathrm{~K} 8$ & 6.2 & 1.3 & - & 0 & 0 & & \\
\hline \multirow[t]{2}{*}{ 副腎ホルモン剂 } & 筋注用ケナコルトーA & $40 \mathrm{mg}$ & $5 \times 6141 M$ & 7.6 & 1.2 & + & & $\bigcirc$ & & \\
\hline & デポメドロール & $40 \mathrm{mg}$ & $\mathrm{ZCO} 12$ & 6.7 & 1.1 & + & 0 & $\bigcirc$ & & \\
\hline \multirow[t]{3}{*}{ 女性ホルモン剂 } & オバホルモンベンツアート & $0.2 \mathrm{mg}$ & EH28E6 & 6.5 & 1.6 & \# & & $\bigcirc$ & & \\
\hline & エストリール水性懸濁 & $10 \mathrm{mg} \quad 1 \mathrm{ml}$ & $\mathrm{S} 51112 \mathrm{Cl} 36 \mathrm{~N} 10$ & 4.3 & 1.0 & + & & $\bigcirc$ & & \\
\hline & 静注用プレマリン & $20 \mathrm{mg}$ & JXAM521WD072 & 7.3 & 1.7 & 冊 & & & 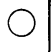 & \\
\hline \multirow{2}{*}{$\begin{array}{c}\text { その他のホルモン剂 } \\
\vdots\end{array}$} & カリクレイン・デポー & 40単位 & $7 \mathrm{G13F}$ (溶解液) & 5.6 & 0.9 & - & & 0 & & \\
\hline & プロラクチン & 100 単位 & HB25BH6 & 8.4 & 0.7 & - & & $\bigcirc$ & & \\
\hline \multirow{2}{*}{$\begin{array}{l}\text { 子宮 収 縮 剂 } \\
\text { 絵合皮虚疾患治療剂 }\end{array}$} & メテルギン & $0.02 \% 1 \mathrm{ml}$ & $882 \mathrm{~L} 5 \mathrm{~T}$ & 3.3 & 0.8 & - & 0 & $\bigcirc$ & ) & $\therefore$ \\
\hline & メチアデカル & $5 m \ell$ & 6096 & 6.9 & 2.5 & H & & & & \\
\hline その他の器官用薬 & ベノプラント & $1.3 \% 5 \mathrm{ml}$ & CJ31 & 8.1 & 3.0 & - & & $\bigcirc$ & 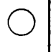 & \\
\hline \multirow[t]{10}{*}{ ビタミン 剤 } & チョコラ A & 5 万単位 & D08EI & 5.0 & 0.9 & - & & $\bigcirc$ & & \\
\hline & アリナミン F 50 & $50 \mathrm{mg} \quad 20 \mathrm{ml}$ & $\mathrm{S} 615$ & 3.5 & 4.8 & + & & & O & \\
\hline & ベストン 50 & $50 \mathrm{mg} \quad 20 \mathrm{~m} \ell$ & 95088 & 4.1 & 1.3 & + & & & 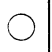 & \\
\hline & ニコチン酸アミド & $1 \mathrm{m \ell}$ & & 7.2 & 1.8 & H & 0 & 0 & & \\
\hline & パントール & $100 \mathrm{mg}$ & EF04 & 5.9 & 2.4 & Hit & 0 & $D$ & 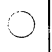 & \\
\hline & フォリアミン & $15 m g$ & OWR014 & 8.4 & 0.8 & - & 0 & $\bigcirc$ & & \\
\hline & パントシン B 10\% & $100 \mathrm{mg}$ & & 5.2 & 1.6 & H & $\bigcirc$ & $\bigcirc$ & & \\
\hline & ユベラ & $100 \mathrm{mg}$ & A09AI & 7.0 & 0.5 & H & & $\bigcirc$ & & \\
\hline & ケイッー & $10 \mathrm{mg}$ & A16LI & 5.9 & 4.7 & - & & $\bigcirc$ & $\bigcirc$ & \\
\hline & ビスコン & $5 m \ell$ & FJF107 & 5.2 & 1.7 & - & & & $\bigcirc$ & \\
\hline \multirow[t]{7}{*}{ 止 血 剂 } & アドナ(AC-17) & $0.5 \% 2 \mathrm{ml}$ & & 5.8 & 1.4 & H & 0 & $\bigcirc$ & & \\
\hline & アドナ(AC-17) & $0.5 \% \quad 5 \mathrm{ml}$ & $64 \neq 22$ & 5.9 & 1.6 & H & & & $\bigcirc$ & \\
\hline & アドナ(AC-17) & $0.5 \% 10 \mathrm{~m} \ell$ & 千390430 & 5.8 & 1.6 & $\#$ & & & $\bigcirc$ & \\
\hline & トロスチン & $0.5 \% \quad 5 \mathrm{~m} \ell$ & A5D001BD & 5.4 & 1.0 & - & & & $\bigcirc$ & \\
\hline & マネトール & $1 \mathrm{ml}$ & Y01019 & 5.7 & 1.4 & - & & $\bigcirc$ & 0 & \\
\hline & イプシロン & $5 \% 20 \mathrm{ml}$ & $1029 \mathrm{TAY}$ & 7.6 & 1.4 & - & 0 & $\bigcirc$ & $\bigcirc$ & \\
\hline & トランサミン & $5 \% \quad 5 \mathrm{ml}$ & $1676 \mathrm{TBZ}$ & 7.6 & 1.1 & - & & $\bigcirc$ & $\bigcirc$ & \\
\hline
\end{tabular}


（表 1 つゔき）

\begin{tabular}{|c|c|c|c|c|c|c|c|c|c|c|}
\hline \multirow{2}{*}{ 薬効分類名 } & \multirow{2}{*}{ 注 射 削 名 } & \multirow{2}{*}{ 規 格 } & \multirow{2}{*}{ 製造番号 } & \multirow{2}{*}{$\mathrm{pH}$ 值 } & \multirow{2}{*}{$\begin{array}{l}\text { 浸透 } \\
\text { 圧比 }\end{array}$} & \multirow{2}{*}{$\begin{array}{l}\text { 溶血 } \\
\text { 性 }\end{array}$} & \multicolumn{3}{|c|}{ 適用部位 } & \multirow{2}{*}{ 備 考 } \\
\hline & & & & & & & 皮下 & 筋 & 静 & \\
\hline 止 血 剂 & トランサミン S & $10 \% 10 \mathrm{~m} \ell$ & $1046 \mathrm{TIY}$ & 7.6 & 2.4 & + & & 0 & 0 & \\
\hline & ヘスナ & $2 m \ell$ & 0031 & 7.9 & 4.9 & - & 0 & 0 & O & \\
\hline & レプチラーゼ $S$ & $1 \mathrm{~m} \ell$ & & 7.1 & 1.2 & - & & 0 & 0 & \\
\hline 血液凝固阻止剂 & ノボ硫酸プロタミン & $1 \% \quad 1 \mathrm{ml}$ & FE16 & 3.3 & 0.8 & + & & & ) & \\
\hline 血 球 用 剂 & ロイコン & $1 \% \quad 2 m \ell$ & A93308 & 6.4 & 1.0 & - & & 0 & ) & \\
\hline & イノシー & $2 \% \quad 10 m \ell$ & & 8.5 & 0.3 & + & & & D & \\
\hline その他の代謝性医薬品 & ミオアクチン C & & MC9092 & 7.2 & 1.3 & + & 0 & 0 & & \\
\hline & トラジロール & 25,000 単位 & YQN4 & 6.2 & 1.0 & - & & & D & \\
\hline & トラジロール & 50,000 単位 & YQ1034 & 6.2 & 1.0 & - & & & D & \\
\hline 抗 生 物 質 & ゼオペン & $1 g$ & $506-360239 \mathrm{BL}$ & 6.1 & 10.1 & $\#$ & & 1 & 0 & 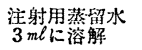 \\
\hline & ペントレックス & $250 \mathrm{mg}$ & PCM 87 & 9.0 & 2.1 & - & & O & 0 & 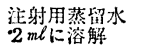 \\
\hline & ペントレックス & $500 \mathrm{mg}$ & $\mathrm{PCP} 4$ & 9.1 & 3.6 & - & & 0 & 0 & 同 $2.5 m \ell に$ 溶解 \\
\hline & リラシリン注射用 & $1 \%$ & 0754 & 5.7 & 1.2 & - & & & 0 & 同 $2.5 m \ell k$ 溶解 \\
\hline & リラシリシ筋注用 & $1 \mathrm{~g}$ & 0498 & 5.9 & 8.7 & + & & 0 & & \\
\hline & ブロードシリン & $100 \mathrm{mg}$ & AVE3 & 8.7 & 0.7 & - & & $\bigcirc$ & & 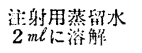 \\
\hline & コリスチンM & 200万単位. & COL38 & 6.6 & 1.4 & H & $\bigcirc$ & 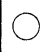 & & 同上 \\
\hline & ゲンタシン & $10 \mathrm{mg}$ & GT197 & 5.2 & 0.8 & H & & O & & \\
\hline & カネンドマイシン & $200 \mathrm{mg}$ & NKNSX27 & 7.0 & 0.9 & - & & O & & \\
\hline & セファメジン筋注:用 & $500 \mathrm{mg}$ & $\mathrm{ZH}-9960$ & 5.5 & 1.8 & - & & ( & & \\
\hline & セポラン & $500 \mathrm{mg}$ & 63241 & 4.9 & 0.4 & - & & 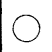 & 0 & $\begin{array}{l}\text { 注射用蒸留水 } \\
2.5 m l に 心 \text { 解解 }\end{array}$ \\
\hline & $\begin{array}{l}\text { 静注用 } \\
\text { ホスホサイクリンーPRM }\end{array}$ & $250 \mathrm{mg}$ & $320 \mathrm{E} 010$ & 5.2 & 0.9 & - & & & 0 & 同10alに溶解 \\
\hline 生物学的製剂 & ヒスタグロビン & & 200 & 7.3 & 0.7 & - & 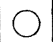 & & & \\
\hline
\end{tabular}

は, かすかに溶血性がみられ，その判定を土とした。こ れらの結果から, 注射剤として望ましい範囲は, 赤石ら の述べた 0.5〜8 より若干狭い範囲の 0.5〜 5 が適当と 考えられる.

c）市販注射剂における pH 值および淡透圧比と溶血

\section{此との関係}

前報で報告した 184 種および今回新たに試験した 96 種の市販注射斑を, 溶血性陰性のもの122 種と溶血性の みられた 158 種に分け，それぞれについて pH 值および 漫透圧比との関係をプロットし，図 1-a， bに示した. その結果, 溶血性陰性の試料は, 浸透圧比 $0.5 \sim 5$ およ び $\mathrm{pH}$ 3.5〜9.5の間にほぼ集中した。また，溶血性のみ られた試料については，その範囲内にあるものも多数み られたが，それ以外の領域に多数散在することが認めら れた.さらに各 $\mathrm{pH}$ 域および各浸透圧比の試料中, 溶血 性のみられた試料の比率を検討した結果, 図 2 および図 3 に示したよらに, 非生理的な $\mathrm{pH}$ 值または浸透圧比を 示す試料においては, 溶血性を示す試料が高率であるこ
とが裏付けられた。これらの結果から， $\mathrm{pH}$ 值範囲につ いては a）で得た結果よりも低い值であったが，市販注 射剂においてもこれらの範团を超えた非生理的な $\mathrm{pH}$ 值 小よび浸透圧比をもったものは，そのほとんどが溶血性 を示すことが確認された。これらのことから，注射剤の 添付文畫に記載された $\mathrm{pH}$ および浸透圧比の值から，そ の溶血性の有無を推測することがある程度可能と考えら れる。

\section{2. 低漫透圧比注射剂の等張化による溶血性の变化}

試験した 280 種の市販注射剂の中から，浸透圧比が低 く, 溶血性のみられた試料 17 種を選び，これらに塩化 ナトリウムを加えて等張化をはかったのち，溶血性を試 験した．その結果，表 4 に示したように，ピレチア，塩 酸パパベリンおよびネオフィリンを除く13 種の試料に, 溶血性の程度の低減をたは陰性化が少られた．溶血性の 陰性化した試料は（州）を示していたペルサンチンをは じめ, エホチール，ビタカンファー，ユベラおよびイノ シーの 5 種であった。 また，塩酸エチレフリン $10 \mathrm{mg}$ 含 
表 2. pH俌と溶血性との関係

\begin{tabular}{|c|c|c|}
\hline $\mathrm{pH}$ 值 & 浸唀压比 & 溶 血 性 \\
\hline 2.11 & 1.1 & \# \\
\hline 2.27 & 1.1 & 曲 \\
\hline 2.60 & 1.1 & W \\
\hline 3.31 & 1.1 & $\#$ \\
\hline 3.88 & 1.1 & $+\sim \#$ \\
\hline 4.08 & 1.1 & + \\
\hline 4.55 & 1.0 & - \\
\hline 4.81 & 1.0 & - \\
\hline 5.14 & 1.0 & - \\
\hline 5.78 & 1.0 & - \\
\hline 6.84 & 1.1 & - \\
\hline 7.77 & 1.0 & - \\
\hline 9.39 & 1.0 & - \\
\hline 9.96 & 1.0 & - \\
\hline 10.41 & 1.0 & - \\
\hline 10.91 & 1.0 & - \\
\hline 11.30 & 1.0 & $H$ \\
\hline 11.53 & 1.1 & HI \\
\hline 11.91 & 1.4 & 册 \\
\hline 12.22 & 2.2 & ' \\
\hline 12.37 & 3.8 & HI \\
\hline
\end{tabular}

有するエホチールおよびブランチルは，前報で述べたよ らに，溶血性陰性の同一主成分含有製剤エチフィール （浸透圧比 1.0）およびアテピナ（同 1.1）と比較して, 浸透圧比の低かった試料である. したがって，この 2 種 の試料に溶血性がみられた原因は，浸透圧比の差異によ るものであることが確認された。

以上の結果から, 低漫透圧比の注射剂の多くは, 等張 化することによって, 溶血性の程度の低減または陰性化 の可能性のあることが明らかとなった. 低張注射剂の等 張化は，製剤技術上容易になしらるものと考兄られるの で，さらに安全性の高い製剤への改良が望まれる。

\section{3. 混合による溶血性の変化}

\section{a)一般注射剂と生理食塩液との混合}

表 3．浸透圧比と溶血性との関係

\begin{tabular}{|c|c|c|}
\hline 浸 & 圧 & \\
\hline $\mathrm{mOsm} / \ell$ & 浸·透压比 & \\
\hline 26 & 0.1 & $H$ \\
\hline 58 & 0.2 & H \\
\hline 93 & 0.3 & $\#$ \\
\hline 119 & 0.4 & + \\
\hline 149 & 0.5 & \pm \\
\hline 179 & 0.6 & - \\
\hline 205 & 0.7 & - \\
\hline 241 & 0.9 & - \\
\hline 269 & 1.0 & - \\
\hline 298 & 1.1 & - \\
\hline 582 & 2.1 & - \\
\hline 868 & 3.1 & - \\
\hline 1,161 & 4.1 & - \\
\hline 1,494 & 5.3 & \pm \\
\hline 1,821 & 6.4 & + \\
\hline 2,103 & 7.4 & + \\
\hline 2,513 & 8.9 & + \\
\hline 2,853 & 10.1 & + \\
\hline
\end{tabular}

生理食塩液 $: 283 \mathrm{mOsm} / \ell$

溶血性の強い注射剂の筋肉内への適用は, 細胞・組織障 害性も強いこと ${ }^{3,4)}$ が知られている。このような注射剤 を筋肉内注射する場合に，溶血性を低減または陰性化す ることが望ましいと考元，生理食塩液，糖類または注射 用蒸留水を除いた一般注射剤（以下一般注射剂と省略） そそれらとの混合による溶血性の変化を検討した．その 一例として, 生理食塩液との混合について試験した.

試料として，（I）漫透圧比が高く，強い溶血性のみ られた注射剂 8 種，(II）適用部位が 皮下をたは筋肉内 に限られており，溶血性の強い注射剂 10 種を選んだ.そ の容量が $1 \mathrm{~m} \ell$ 場合には生理食塩液の 混合量を 0.5 ,

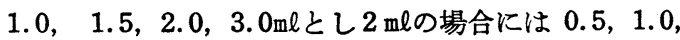
$1.5,2.0 \mathrm{~m} \ell$ として溶血性を試験し，その結果を表 5 お よび表 6 に示した.（I）においては，10\%および 20 


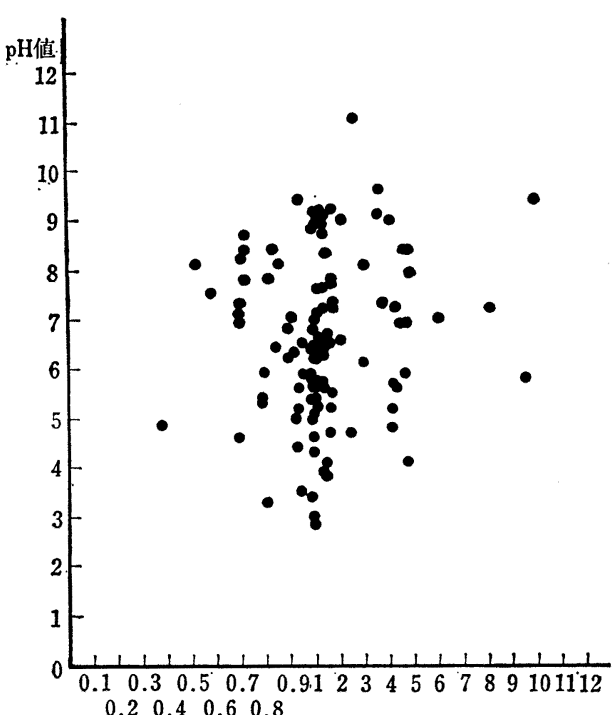

図 1-a 浸透压比

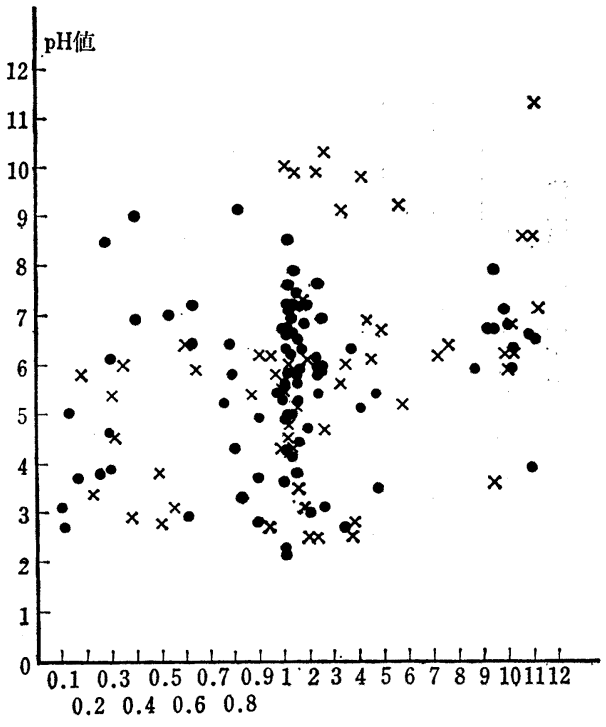

図 1-b 浸透圧比

図 1. 市販注射剤のpH值と浸透圧比との関係

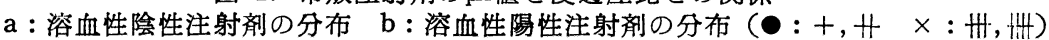

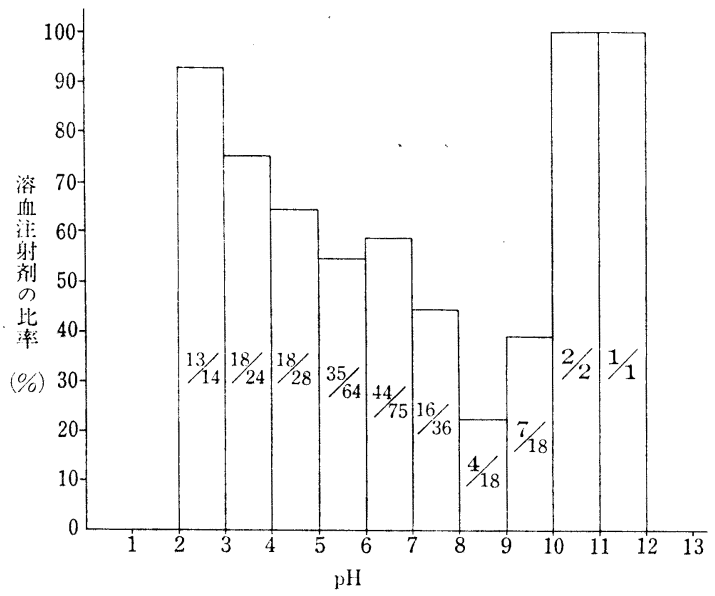

図 2. 各pH域における溶血性を有する注射凧の比率

\%フェノバールは白色沈殿が生じて混合は不可であった が，その他の 6 種は，浸透圧比の低下に伴って溶血性の 低減・陰性化がみられた。特に，サンピリン 1 号および 2 号は, 生理食塩液 $1 \mathrm{ml}$ 混合により（姍）から（一) に変化した。 また（II）に扔いても同様の結果がみられ たが，いずれの試料も等張に近いものであるため，その ほとんどが生理食塩液 $0.5 \mathrm{ml}$ 混合で，溶血性の低減ま たは陰性化がみられた。これらの結果から，溶血性の強 い注射剂の皮下または筋肉内注射に際しては，適量の生 理食塩液等を混合することによって，使用上の安全性が 得られると考えられる．また，製凧的には，容量の変更
によるさらに安全性の高い製剤への改良について検討す ることが望まれる。

\section{b) 一般注射剂間の混合}

当院で行われている筋肉内適用混注例のらち，11例に ついて溶血性执よび物理的性状の变化を検討した。その 結果, 表 7 に示したように, ソセゴンサアタラックス - P, ソセゴントアタラックス-P+硫酸アトロピン，サ ンピリン 2 号+レスタミン 2 号の混合例を除いて,全体的 に溶血性の低減がみられること文が確認された。一般に， 混合注射剂の溶血性はその低い方の溶血性の程度に合致 する傾向がみられたが,ゲンタシン+サンピリン 1 号, レ 


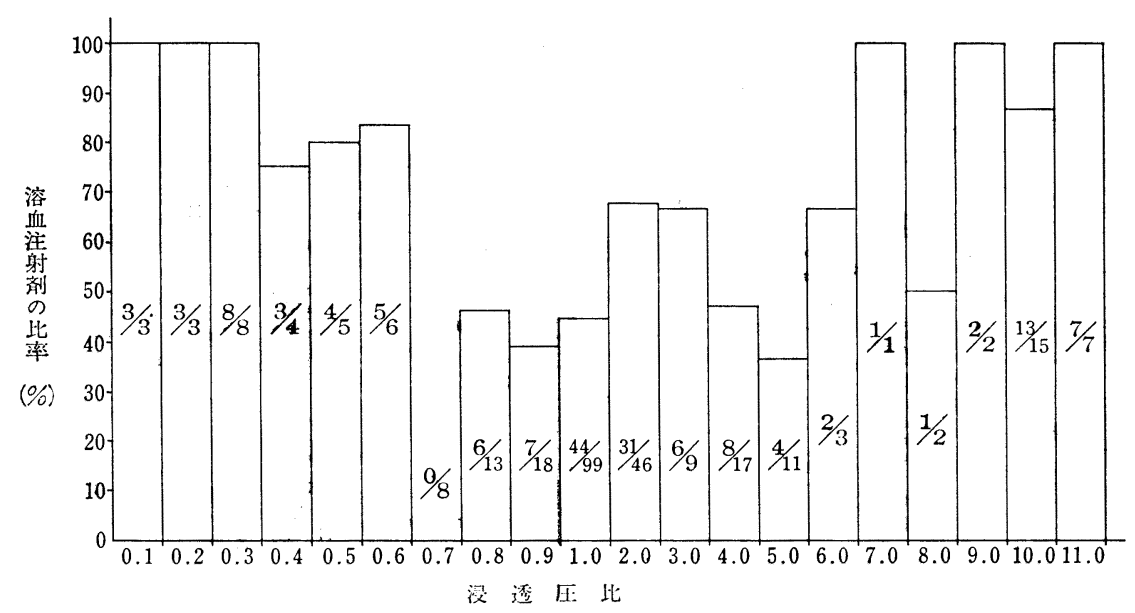

図 3. 各浸透圧比における溶血性を有する注射剤の比率

表 4 . 低浸透圧比注射㣂の等張化による溶血性の変化

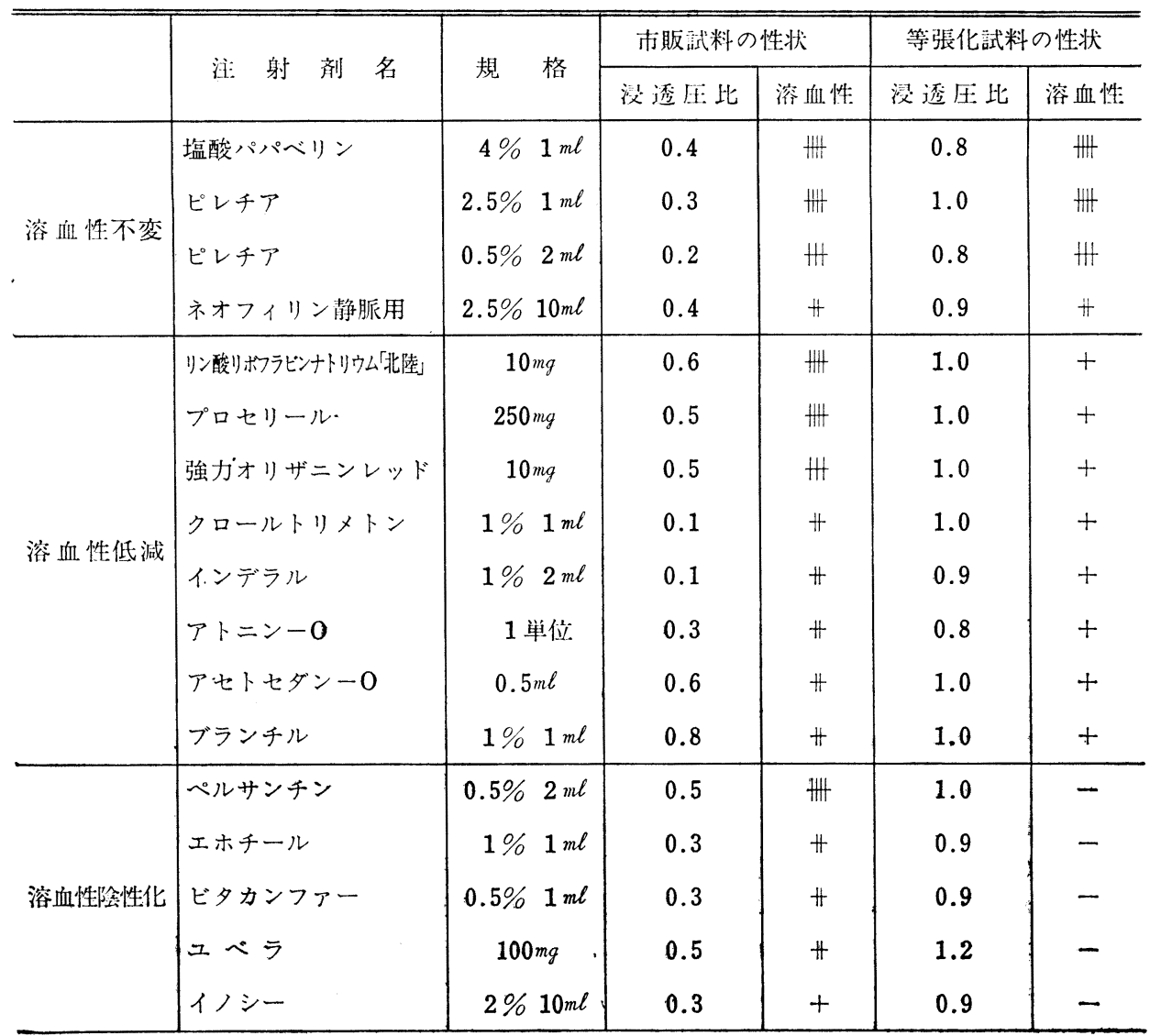


スタミン 1 号+サンピリン 1 号の混合においてい, それ ン 1 号の浸透圧比の低下による溶血性の低減程度が, ゲ よりさらに低隇した．この理由は，さきのサンピリン 1 ンタシンおよびレスタミン 1 号の溶血性の程度を下まわ 号と生理食塩液混合の例と併せて考察すると, サンピリ るためであろらと推察される.

表 5 ．生理食塭液の䍡合による溶血性の変化(I)

\begin{tabular}{|c|c|c|c|c|c|c|}
\hline \multirow{2}{*}{ 注射剂名および規格 } & \multirow{2}{*}{ 浸透圧比 } & \multirow{2}{*}{ 溶 血 性 } & \multicolumn{3}{|c|}{ 生理食塩液混合による変化 } & \multirow{2}{*}{ 備：考 } \\
\hline & & & 混合量 $m \ell$ & 浸透圧比 & 溶血性 & \\
\hline $\begin{array}{l}\text { フェノバール } \\
10 \% \quad 1 m \ell\end{array}$ & 11.0 & WI & $\begin{array}{l}0.5 \\
1.0 \\
\end{array}$ & 9.0 & HAt & 白色沈殿 \\
\hline $\begin{array}{l}\text { フェノバール } \\
20 \% \quad 1 m \ell\end{array}$ & 10.6 & HAH & $\begin{array}{l}0.5 \\
1.0\end{array}$ & & & $\begin{array}{l}\text { 白色沈殿 } \\
\text { 白色沈殿 }\end{array}$ \\
\hline $\begin{aligned} \text { サンピリン } 1 \text { 号 } \\
$\[ 1 \mathrm{m \ell} \]$\end{aligned}$ & 10.2 & HII & $\begin{array}{l}0.5 \\
1.0 \\
2.0\end{array}$ & $\begin{array}{l}4.4 \\
3.5 \\
2.6 \\
\end{array}$ & $\begin{array}{l}+ \\
- \\
-\end{array}$ & . \\
\hline 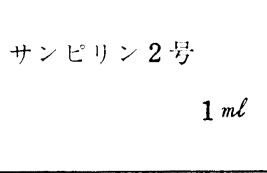 & 11.3 & 曲 & $\begin{array}{l}0.5 \\
1.0 \\
2.0\end{array}$ & $\begin{array}{r}10.6 \\
7.7 \\
5.0\end{array}$ & $\begin{array}{c}\text { HIt } \\
- \\
-\end{array}$ & \\
\hline オベロン & 5.7 & HI & $\begin{array}{l}0.5 \\
1.0 \\
2.0 \\
3.0\end{array}$ & $\begin{array}{l}4.2 \\
3.4 \\
2.6 \\
2.2 \\
\end{array}$ & $\begin{array}{l}H \\
W \\
H \\
-W \\
-\end{array}$ & \\
\hline $\begin{array}{l}\text { レセラ } \\
\quad 0.05 \% \quad 1 \mathrm{ml}\end{array}$ & 9.5 & HWt & $\begin{array}{l}0.5 \\
1.0 \\
2.0 \\
3.0 \\
4.0\end{array}$ & $\begin{array}{l}6.2 \\
4.8 \\
3.5 \\
2.9 \\
2.5 \\
\end{array}$ & $\begin{array}{l}\text { H } \\
W \\
H \\
H \\
- \\
-\end{array}$ & \\
\hline $\begin{array}{l}\text { セルシン } \\
\qquad 10 \mathrm{mg} \quad 2 \mathrm{ml}\end{array}$ & 10.9 & H & $\begin{array}{l}0.5 \\
1.0 \\
1.5 \\
2.0 \\
\end{array}$ & $\begin{array}{r}10.4 \\
9.7 \\
9.5\end{array}$ & $\begin{array}{l}+ \\
+ \\
+ \\
+\end{array}$ & 白渱 \\
\hline $\begin{array}{c}\text { デスラノシド(北陸) } \\
0.02 \% 2 m\end{array}$ & 10.1 & $\#$ & $\begin{array}{l}0.5 \\
1.0 \\
1.5\end{array}$ & $\begin{array}{r}10.1 \\
10.0 \\
7.6\end{array}$ & $\begin{array}{l}\# \\
+ \\
-\end{array}$ & \\
\hline
\end{tabular}


表 6 . 生理食塩液の混合による溶血性の変化(II)

\begin{tabular}{|c|c|c|c|c|}
\hline \multirow{2}{*}{ 注 射 剂 名 } & \multirow{2}{*}{ 規 } & \multirow{2}{*}{ 溶 血 性 } & \multicolumn{2}{|c|}{ 生理食塩液混合後の変化 } \\
\hline & & & 混合量 $m l$ & 溶 血 性 \\
\hline \multirow{4}{*}{ アポプロン } & \multirow{4}{*}{$0.05 \%$} & \multirow{4}{*}{ 冊 } & 0.5 & $H$ \\
\hline & & & 1.0 & \# \\
\hline & & & 2.0 & + \\
\hline & & & 3.0 & - \\
\hline \multirow{4}{*}{ レスタミン 1 号 } & \multirow{4}{*}{$1 \%$} & \multirow{4}{*}{ H } & 0.5 & \# \\
\hline & & & 1.0 & \# \\
\hline & & & 2.0 & + \\
\hline & & & 3.0 & + \\
\hline \multirow{4}{*}{ レスタミン 2 号 } & \multirow{4}{*}{$1.5 \% 2 \mathrm{ml}$} & \multirow{4}{*}{ H } & 0.5 & H \\
\hline & & & 1.0 & \# \\
\hline & & & 1.5 & \# \\
\hline & & & 2.0 & H \\
\hline \multirow{3}{*}{ スメルモン } & \multirow{3}{*}{$1 \mathrm{ml}$} & \multirow{3}{*}{ \# } & 0.5 & + \\
\hline & & & 1.0 & + \\
\hline & & & 2.0 & - \\
\hline \multirow{3}{*}{ ズファジラン } & \multirow{3}{*}{$0.5 \%$} & \multirow{3}{*}{ \# } & 0.5 & \# \\
\hline & & & 1.0 & + \\
\hline & & & 2.0 & - \\
\hline \multirow{4}{*}{ テラプチク筋注 } & \multirow{4}{*}{$1.5 \% 2 m l$} & \multirow{4}{*}{$\#$} & 0.5 & + \\
\hline & & & 1.0 & + \\
\hline & & & 1.5 & + \\
\hline & & & 2.0 & - \\
\hline \multirow{2}{*}{ ノルアドレナリン } & \multirow{2}{*}{$0.1 \% 1 \mathrm{ml}$} & \multirow{2}{*}{ \# } & 0.5 & - \\
\hline & & & 1.0 & - \\
\hline \multirow{2}{*}{ オバホルモンベンッアート } & \multirow{2}{*}{$0.2 \mathrm{mg} 1 \mathrm{~m} \ell$} & \# & 0.5 & - \\
\hline & & $\pi$ & 1.0 & - \\
\hline .ゲンタシン & $10 \mathrm{mg} 1 \mathrm{ml}$ & t & 0.5 & \# \\
\hline 7 & Jong 1 he & $\pi$ & 1.0 & - \\
\hline & $40 \mathrm{mo} 1 \mathrm{ml}$ & + & 0.5 & - \\
\hline 胁社用T TUR-A & 40 my 1 me & $T$ & 1.0 & - \\
\hline
\end{tabular}


表 7 ．市販注射剤の混合による性状の変化

\begin{tabular}{|c|c|c|c|c|c|c|c|}
\hline \multirow{2}{*}{ 混 今注 射 刘 } & \multirow{2}{*}{ 規 格 } & \multicolumn{3}{|c|}{ 単 } & \multicolumn{2}{|l|}{ 混 } & 後 \\
\hline & & $\mathrm{pH}$ 值 & 浸透圧比 & 溶 血 性 & $\mathrm{pH}$ 值 & 浸透圧比 & 溶 血 性 \\
\hline $\begin{array}{l}\text { スメルモン } \\
\text { レスタミン } 2 \text { 号 }\end{array}$ & $\begin{array}{c}1 \mathrm{~m} \ell \\
1.5 \% 2 \mathrm{~m} \ell\end{array}$ & $\begin{array}{l}4.9 \\
6.2\end{array}$ & $\begin{array}{l}1.2 \\
0.9\end{array}$ & $\begin{array}{l}+ \\
H\end{array}$ & 5.3 & 1.0 & H \\
\hline $\begin{array}{l}\text { スメルモン } \\
\text { レスタミン } 2 \text { 䒚 } \\
\text { ソセゴン }\end{array}$ & $\begin{array}{c}1 \mathrm{m \ell} \\
1.5 \% 2 \mathrm{m \ell} \\
30 \mathrm{mg}\end{array}$ & $\begin{array}{l}4.9 \\
6.2 \\
4.2\end{array}$ & $\begin{array}{l}1.2 \\
0.9 \\
1.1\end{array}$ & $\begin{array}{l}H \\
H \\
H\end{array}$ & 4.2 & 1.1 & H \\
\hline $\begin{array}{l}\text { スメルモン } \\
\text { ソセゴン }\end{array}$ & $\begin{array}{l}1 m \ell \\
30 m g\end{array}$ & $\begin{array}{l}4.9 \\
4.2\end{array}$ & $\begin{array}{l}1.2 \\
1.1\end{array}$ & $\begin{array}{l}H \\
+4\end{array}$ & 4.2 & 1.2 & $H$ \\
\hline $\begin{array}{l}\text { スメルモン } \\
\text { ソセゴン } \\
\text { 硫酸アトロピン }\end{array}$ & $\begin{array}{c}1 \mathrm{~m} \ell \\
30 \mathrm{mq} \\
0.05 \% 1 \mathrm{~m} \ell\end{array}$ & $\begin{array}{l}4.9 \\
4.2 \\
5.9\end{array}$ & $\begin{array}{l}1.2 \\
1.1 \\
1.0\end{array}$ & $\begin{array}{l}+1 \\
- \\
-\end{array}$ & 4.2 & 1.1 & H \\
\hline $\begin{array}{l}\text { ソさゴン } \\
\text { アタラックスーP }\end{array}$ & $\begin{array}{l}30 \mathrm{mg} \\
50 \mathrm{mg}\end{array}$ & $\begin{array}{l}4.2 \\
4.8\end{array}$ & $\begin{array}{l}1.1 \\
1.2\end{array}$ & HIH & 4.2 & 1.2 & HW \\
\hline $\begin{array}{l}\text { ソセゴン } \\
\text { アタラックスーP } \\
\text { 硫酸アトロピン }\end{array}$ & $\begin{array}{c}30 \mathrm{mg} \\
50 \mathrm{mg} \\
0.05 \% 1 \mathrm{ml}\end{array}$ & $\begin{array}{r}4.2 \\
4.8 \\
\\
5.9 \\
\end{array}$ & $\begin{array}{l}1.1 \\
1.2 \\
1.0\end{array}$ & $\begin{array}{l}\text { Hill } \\
4 \\
-\end{array}$ & 4.2 & 1.2 & HI \\
\hline $\begin{array}{l}\text { サンピリン } 2 \text { 少 } \\
\text { ブスコハン }\end{array}$ & $\begin{array}{l}50 \% 1 \mathrm{ml} \\
2 \% 1 \mathrm{ml}\end{array}$ & $\begin{array}{l}7.1 \\
4.4\end{array}$ & $\begin{array}{r}11.3 \\
0.9\end{array}$ & $\begin{array}{l}\text { H } \\
-\end{array}$ & 6.6 & 7.8 & $H$ \\
\hline $\begin{array}{l}\text { サンピリン } 2 \text { 劣 } \\
\text { レスタミン } 2 \text { 晃 }\end{array}$ & $\begin{array}{c}1 \mathrm{~m} \ell \\
1.5 \% 2 \mathrm{ml}\end{array}$ & $\begin{array}{l}7.1 \\
6.2 \\
\end{array}$ & $\begin{array}{r}11.3 \\
0.9\end{array}$ & $\begin{array}{l}H \\
H\end{array}$ & 6.6 & 4.6 & HII \\
\hline $\begin{array}{l}\text { サンピリン } 1 \text { 尖 } \\
\text { セポラン* }\end{array}$ & $\begin{array}{l}25 \% 1 \mathrm{~m} \ell \\
500 \mathrm{mg}\end{array}$ & $\begin{array}{l}6.8 \\
4.9\end{array}$ & $\begin{array}{r}10.2 \\
0.4\end{array}$ & $\begin{array}{l}\text { HII } \\
-\end{array}$ & 6.2 & 3.0 & - \\
\hline $\begin{array}{l}\text { ゲンタシン } \\
\text { サンピリン } 1 \text { 号 }\end{array}$ & $\begin{array}{l}10 \mathrm{mg} \\
1 \mathrm{~m} \ell\end{array}$ & $\begin{array}{l}5.2 \\
6.8 \\
\end{array}$ & $\begin{array}{r}0.8 \\
10.2 \\
\end{array}$ & $\begin{array}{l}H \\
4\end{array}$ & 5.9 & 3.5 & + \\
\hline $\begin{array}{l}\text { サンピリン } 1 \text { 号 } \\
\text { レスタミン } 1 \text { 号 }\end{array}$ & $\begin{array}{l}1 \mathrm{ml} \\
1 \% 1 \mathrm{ml}\end{array}$ & $\begin{array}{l}6.8 \\
6.2\end{array}$ & $\begin{array}{c}10.2 \\
0.9\end{array}$ & $\begin{array}{l}\text { WI } \\
\text { H }\end{array}$ & 6.7 & 3.5 & \# \\
\hline
\end{tabular}

*生理食塭液 $2.5 \mathrm{~m} \ell$ に溶解

\section{結}

1. 各 $\mathrm{pH}$ 值，浸透圧比に調製した試料溶液を用いた実 験結果から,一般に溶血性は $\mathrm{pH} 4.5 \sim 11.0$, 浸透圧比 0.5〜5 の範囲内において陰性であった．また，市販注 射剤においても，ほぼそれらの範囲を超えるものは，ほ
とんどが溶血性を示した。

2. 浸透圧比が低く，溶血性のみられた注射剂 17 種を 塩化ナトリウムで等張化したところ，13 種に溶血性の 程度の低減または除性化がみられ，製剤上の等張化の必 要性が確認された。

3. 溶血性のみられた注射剂のうち，浸透圧比の高い 
もの 8 種, 適用部位が皮下または筋肉内に限られている もの10 種について，生理食塩液を混合したところ，そ のほとんどが生理食塩液混合量 $2 \mathrm{ml}$ 以下で溶血性の低減 または陰性化がみられた。また，一般注射剤間の混合11 例について溶血性を試験したところ，一般に溶血性の低 減がみられた。
文

献

1）田中尚純，森 達雄：病院薬学，2 (3), 138-146 (1976).

2) L. Michaelis : Biochem. Z. 234, 139 (1931).

3）赤石 英, 押田茂実, 高橋由美子: 月刊薬事, 16, 901 (1974).

4) 清水克祐, 新道 功, 大塚静江, 柄松勝己, 川村 正彦：月刊薬事，17，136，539 (1975)。
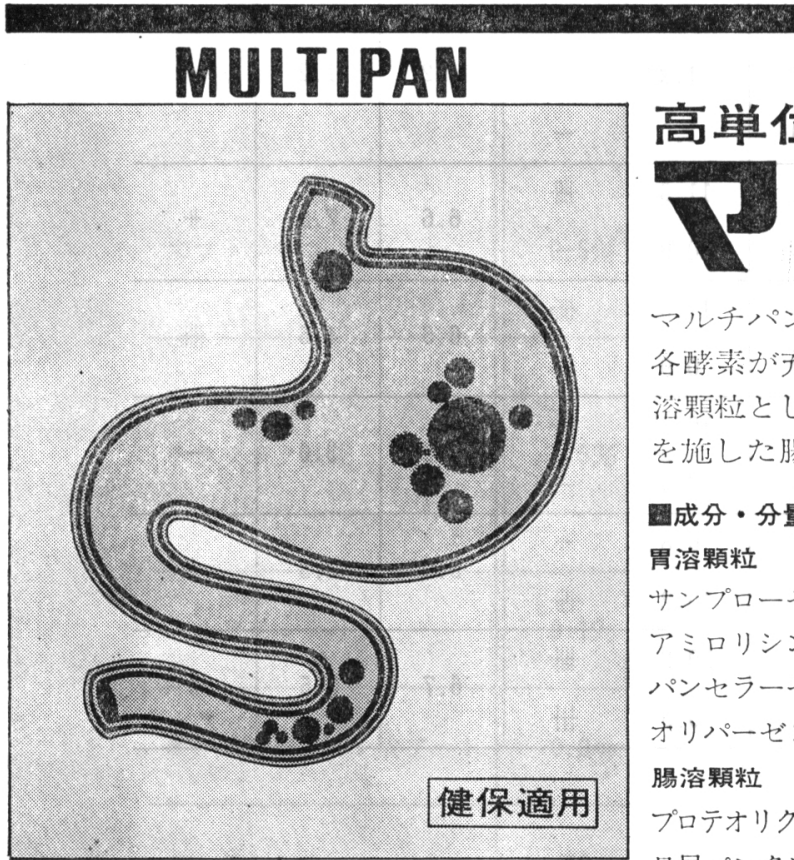

マルチパンは日本人の㱏生活に適合した消化醭素剂であり、 行醏素が充分その作用を発揮するよう胃で作用主るものは胃 溶顆粒とし、晹で作用するものはエンテリックコーティング を施した腸溶顆粒として裂剂化しています。

\section{国成分・分量（1錠中）}

\section{胃溶顆粒}

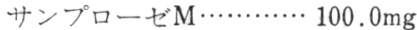

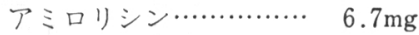

パンセラーゼ…......... $30.0 \mathrm{mg}$

オリパーゼ $2 \mathrm{~S} \cdots \cdots \cdots \cdots .60 .0 \mathrm{mg}$

腸溶顆粒

プロテオリクィファーセ゚‥ 20.0m 日局パンクレアチン……120.0mg
適症

消化不良、過食時の消化促進、消 化不良性下浰、各種扊想による消 化機能障慧、手術後の消化力娍退。

\section{圆用法・用量}

1 回 1 錠、1 日 3 回、位可以または 位直後、㖥まずに経口投与します。 重症の場合は適宜增量します。

畒包装

1,000 錠 5,000 錠 